\title{
Are the health benefits of fish oils limited by products of oxidation?
}

\author{
Rufus Turner, Carlene H. McLean and Karen M. Silvers* \\ New Zealand Institute of Crop \& Food Research, Private Bag 4704, Christchurch, New Zealand
}

\begin{abstract}
Human clinical trials have shown that fish oils reduce the risk of a variety of disorders including CVD. Despite this, results have been inconsistent. Fish oils are easily oxidised and some fish oils contain higher than recommended levels of oxidised products, but their effects have not been investigated. Recent evidence indicates that dietary oxidised fats can contribute to the development of atherosclerosis and thrombosis. This review summarises findings from cellular, animal and human trials that have examined the effects of oxidised lipids and their potential to affect health outcomes, and proposes that oxidised products in fish oils may attenuate their beneficial effects. More research is required to determine the magnitude of negative effects of fish oil on health outcomes in clinical trials.
\end{abstract}

Fish oils: Oxidised lipids: Hydroperoxides: Human clinical trials: Animals: Cells

\section{Introduction}

The consumption of fish oils is beneficial for a variety of health outcomes. The major benefit demonstrated to date has been a reduction in the risk of CVD (Burr et al. 1989; Valagussa et al. 1999; Bucher et al. 2002; Calder, 2004a; Okuda et al. 2005; Schmidt et al. 2005b). Fish oils also have anti-inflammatory properties (Calder, 2004b). These are thought to improve tenderness and stiffness in the treatment of rheumatoid arthritis, although relatively high doses $(4-5 \mathrm{~g} / \mathrm{d})$ of fish oil are required for an effect (Cleland et al. 2003). The role of fish oils in brain function and mental health has also been investigated with studies showing beneficial effects on pre- and postnatal brain development (Jorgensen et al. 1999; Helland et al. 2003). Other studies have found that low fish consumption is associated with depression and other mental conditions (Adams et al. 1996; Hibbeln, 1998; Silvers \& Scott, 2002; Heude et al. 2003).

Fish oil composition varies markedly depending on a variety of factors including fish species, sex and season. Fish oils tend to contain relatively high concentrations of longchain $n$-3 PUFA of which EPA and DHA are the most prominent (Fig. 1). They also contain relatively high levels of tocopherol. Fish oils are available to consumers either in free form or in capsules.

Epidemiological evidence suggests that the intake of high levels of $n-3$ PUFA found in the flesh of oily fish or the livers of lean fish, such as, cod-liver oil, is associated with a reduced risk of CHD (Hu \& Willett, 2002; De Caterina et al. 2003; Lee \& Lip, 2003; Harrison \& Abhyankar, 2005). This is further supported by the results of randomised controlled trials in the treatment of patients with heart disease (Burr et al. 1989; Valagussa et al. 1999). After supplementation with fish oil capsules, these patients had a longer life expectancy with a greater reduction in the risk of fatal myocardial infarctions.

However, randomised controlled trials investigating the potential effects of fish oils on markers of heart disease have produced inconsistent results. A meta-analysis of randomised controlled trials involving patients with heart disease indicated that the relative risk of sudden death for those taking fish oil capsules (containing 0.9-9 g EPA and DHA/d, combined) was 0.7 (95\% CI 0.6, 0.8) compared with placebo (Bucher et al. 2002). Another meta-analysis, investigating the effects of fish oil supplementation (1-7 g EPA and DHA/d) on serum lipids and lipoproteins (Harris, 1997), indicated that the major beneficial effect of fish oil supplementation was a $25 \%$ reduction in triacylglycerol levels in human subjects.

While both meta-analyses aimed to determine the effects of consuming moderately high levels of EPA and DHA, the effects of the same dose on cholesterol and triacylglycerols varied considerably between the studies included in the meta-analyses, some finding a reduction in cholesterol levels whilst others found small increases. The degree of triacylglycerol reduction also varied by over $100 \%$ but this may have been related to the original sample population. However, there appeared to be little or no correlation between the quantity of fish oil consumed and the degree of triacylglycerol reduction or effect on cholesterol levels. In addition, the consumption of low levels of fish oil did not appear to reduce triacylglycerols

\footnotetext{
Abbreviations: HODE, hydroxide; HPODE, hydroperoxide; PV, peroxide value.

* Corresponding author: Dr Karen M. Silvers, P.O. Box 41043, Christchurch, New Zealand, fax + 6433252074 , email karen.silvers@xtra.co.nz
} 
(a)

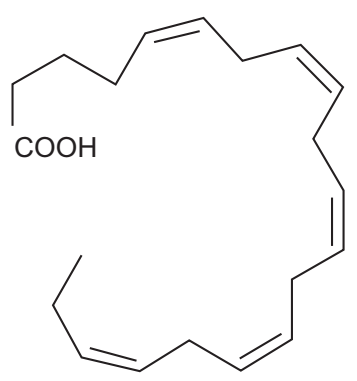

(b)

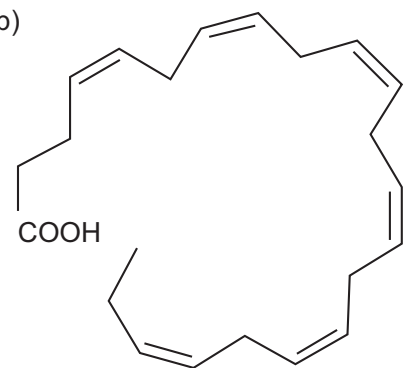

Fig. 1. Very-long-chain $n-3$ PUFA commonly found in fish oils: (a) EPA (20:5n-3); (b) DHA (22:6n-3).

but did increase total and LDL-cholesterol. For instance, an intake of $0.7 \mathrm{~g}$ DHA/d had no significant effects on triacylglycerol levels compared with placebo, but did increase LDL-cholesterol by a net $7 \%$ (Theobald et al. 2004).

There are also inconsistencies in the literature regarding the effect of fish oils and other preparations of $n-3$ PUFA on LDL-cholesterol concentrations, with some showing an increase and others a decline (Kaul et al. 1992). In some studies, an increase in LDL-cholesterol was observed (Leigh-Firbank et al. 2002; Wilkinson et al. 2005). However, the amount of atherogenic LDL-3 cholesterol decreased by more than $22 \%$ at the same time, thus suggesting a reduction in atherogenic risk profile.

There are several possible explanations for the inconsistencies. These include the quantity and composition of fish oil (Kris-Etherton et al. 2003; Buckley et al. 2004; Kew et al. 2004), the CHD risk of participants (Marckmann \& Gronbaek, 1999) and the participant's genotype (Minihane et al. 2000). However, the degree of fish oil oxidation has not been discussed previously.

Fish oils are oxidised during processing and after encapsulation (Hamilton et al. 1998; Undeland et al. 1998; Baik et al. 2004). Potential routes of lipid oxidation include auto-oxidation, photo-oxidation and metal-catalysed oxidation, as well as ionically catalysed oxidation (Frankel, 2005). EPA and DHA are more susceptible to lipid oxidation than other fatty acids under identical conditions because they have a relatively high number of double bonds (unsaturation) and readily form hydroperoxides (HPODE; the initial degradation product in free radicalcatalysed lipid oxidation). This paper reviews the influence that lipid oxidation products in fish oils may have on health outcomes.

\section{Fish oils}

Oil extracted from marine animals is a valuable source of $n$ 3 PUFA but is also an extremely unstable product. Fish oil is obtained primarily from fish rendering plants during the processing of whole or filleted fish bodies into fishmeal. These products are mainly used in the agriculture and aquaculture sectors as fertiliser and fish feed, with only about $2 \%$ of the resulting fish oil used in products for human consumption in 2000 (Barlow, 2000).

As the demand for human consumption has risen, fish oil is increasingly being packaged as a high-value niche product. However, the processing and handling of the raw material has changed little. As a result, the quality of fish oil products on the market has been generally poor, due to the instability and rapid oxidation of the very-long-chain $n-3$ PUFA (Hamilton et al. 1998). To counter this, some crude oil from fishmeal plants is refined to improve its organoleptic properties for human consumption (Venugopal \& Shahidi, 1998).

\section{Oxidation of fish oils}

Oil degradation through oxidation occurs when unsaturated fats come into contact with atmospheric $\mathrm{O}_{2}$. This oxidative process may be accelerated by the presence of metals and by exposure to light and heat. Fish oils are more vulnerable to oxidative degradation because they contain higher quantities of very-long-chain $n$-3 PUFA (Fig. 1) than vegetable or other animal fats (Khayat \& Schwall, 1983).

Auto-oxidation (Fig. 2 (a)) is the major oxidative reaction in oils, and involves the formation of free radicals in the presence of 'initiators'. Initiators catalyse the removal of a hydrogen ion from an unsaturated fatty acid bond. Examples of these include HPODE and transition metals, both of which are common in foods (Frankel, 2005).

The other common oxidation reaction in oils is photooxidation (Fig. 2 (b)). With light exposure (UV radiation)

(a)

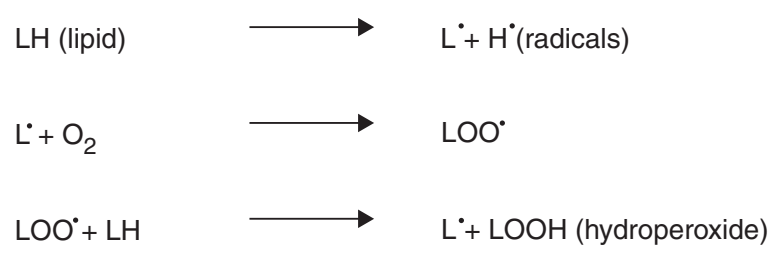

(b)

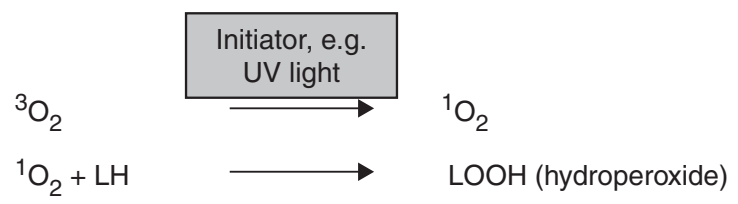

Fig. 2. (a) The auto-oxidation and free radical formation of hydroperoxides. (b) The photosensitised formation of hydroperoxides. L, lipid. 
and a sensitiser (chemicals that can be excited by UV radiation) present, triplet oxygen $\left({ }^{3} \mathrm{O}_{2}\right)$ is converted to singlet oxygen $\left({ }^{1} \mathrm{O}_{2}\right)$, which then interacts with fatty acid double bonds to form lipid HPODE. This type of reaction occurs at a more rapid rate than auto-oxidative reactions owing to the low activation energy required (Min \& Boff, 2002). The products of photo-oxidation can often initiate further auto-oxidation reactions (Frankel, 1991).

The primary products of lipid oxidation are known as HPODE. Over time, these compounds break down into secondary oxidation products (aldehydes and ketones) which cause the unpleasant odours associated with rancid oils. These may eventually break down into short-chain tertiary products (Fig. 3).

Antioxidants are usually added to fish oils to prolong their shelf life and preserve their organoleptic properties. Radical scavenging is the main mechanism by which antioxidants protect foodstuffs (Pokorny et al. 2001). However, antioxidants vary in their ability to prevent auto-oxidation and photo-oxidation. For example, free radical scavengers, such as vitamin $\mathrm{C}$, anthocyanins and phenolics, are most effective against auto-oxidation, whereas singlet oxygen quenchers, such as flavonoids, $\beta$-carotene, and tocopherols, are most effective against photo-oxidation (Gunstone, 1999). Antioxidants can also work by inhibiting oxidation enzymes, for example, flavonoids, or by chelating prooxidant metals, such as, citric acid.

Oxidative degradation of fish oils begins while the fish is still alive, induced by the stress of ageing and then capture (Passi et al. 2004). The rate of $n-3$ PUFA degradation rapidly increases when the fish is processed, as tissue lipids are subsequently exposed to pro-oxidants such as atmospheric $\mathrm{O}_{2}$ (Undeland et al. 1998) and to endogenous metals and enzymes (Richards \& Li, 2004). As a result, amounts of EPA and DHA tend to decrease, while the peroxide value (PV), an indicator of the degree of primary oxidation product, increases (Fritsche \& Johnston, 1987).

During the common 'wet-reduction' method of commercial fish oil production, the fish is cooked (about $100^{\circ} \mathrm{C}$ ) to facilitate tissue protein coagulation and promote oil expression. The product is then pressed and centrifuged, during which the oil is exposed to both $\mathrm{O}_{2}$ and heat for several hours (Bimbo, 1987). Oil produced from typical fishmeal production processes is likely to have a PV ranging from 6 to $22 \mathrm{mEq} \mathrm{O}_{2} / \mathrm{kg}$, depending on processing and handling conditions, and will oxidise further in the absence of antioxidants (Fritsche \& Johnston, 1987). Once the oil is extracted and clarified, it is generally stored in large drums. The PV may be temporarily retarded at this stage if antioxidants are added and there is no headspace in storage containers. However, oxidation will continue once the containers are opened and the oil is further processed.

Our research shows that currently available commercial fish oil supplements contain varying levels of primary and secondary oxidation products $(\mathrm{CH}$ McLean, unpublished results). Table 1 shows the results of testing commercial fish oil supplements for PV and $p$-anisidine value. $p$-Anisidine value is an indicator of levels of secondary oxidation products, i.e. aldehydes and ketones (Aidos et al. 2001). It is important to measure both $p$-anisidine values and PV when looking at oil quality, as together they give a more accurate profile of the condition of the oil. Specifications for foodgrade oils usually indicate a maximum PV of $2 \mathrm{mEq} \mathrm{O}_{2} / \mathrm{kg}$ and a $p$-anisidine value of 10 , but the values in Table 1 show that most commercially available fish oils do not meet these specifications.

\section{Effects of oxidised lipids on health}

Cellular, animal and human studies have investigated the effects of dietary oxidised lipids on a range of biomarkers of disease, including lipid metabolism, oxidative stress and inflammation. The effects on each biomarker are discussed in turn. Although none of the products of oxidation have been derived from fish oils, it is envisaged that the outcomes would be similar.

\section{Lipid and chylomicron metabolism}

Lipid and chylomicron metabolism are factors used to determine the risk of CVD (Roche \& Gibney, 2000; Rivellese et al. 2003). This risk can be assessed in both the fasted and postprandial states.

Cellular studies. To date, most research on the effects of HPODE and hydroxy derivatives (hydroxides; HODE) in animal and human cells has focused on vascular smooth muscle cells. Cellular studies have indicated that oxidised linoleic acid modifies cholesterol metabolism. 13-HPODE and 13-HODE were found to compete with linoleic acid for absorption across the cell monolayer when 13-HPODE, 13-HODE and linoleic acid were incubated together with a human colon cancer cell line (CaCo-2 cells; Muller et al. 2002). This competition led to a decrease in the amount of linoleic acid and an increase in hydroxy fatty acids in released triacylglycerols. The resulting increase in hydroxy fatty acids was then incorporated into lipoproteins, thus increasing their susceptibility to oxidation (Muller et al. 2002).

In addition, oxidised linoleic acid is potentially atherosclerotic, as it increases the solubility of cholesterol in

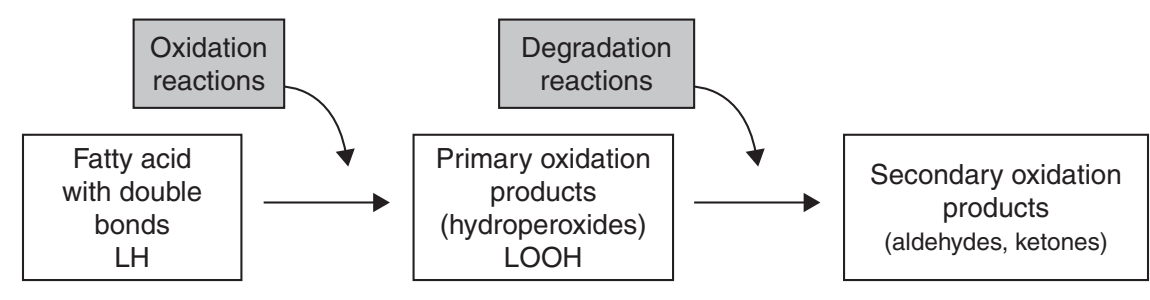

Fig. 3. General process of lipid oxidation. L, lipid. 
Table 1. Measure of oxidation products in commercial fish oil supplements

\begin{tabular}{lcc}
\hline Brand & $\begin{array}{c}\text { Peroxide } \\
\text { value }\left(\mathrm{mEq} \mathrm{O}_{2} / \mathrm{kg}\right)^{*}\end{array}$ & $\begin{array}{c}p \text {-Anisidine } \\
\text { value† }\end{array}$ \\
\hline Brand A & 4.1 & 11 \\
Brand B & 5.4 & 9 \\
Brand C & 3.5 & 15 \\
Brand D & 4.6 & 17 \\
Brand E & 3.2 & 16 \\
Brand F & 5.5 & 20 \\
\hline
\end{tabular}

* 'Peroxide 'Value of Oils and Fats', AOAC official method 965.33 (Association of Official Analytical Chemists, 1990). † AOCS official method CD 18-90 (American Oil Chemists Society, 1998).

micelles, thereby increasing cholesterol uptake in $\mathrm{CaCo}-2$ cells. This effect has been attributed to the fact that oxidised linoleic acid (13-hydroxy linoleic acid) and lithocholic acid, a bile acid used in the solubilisation of cholesterol in micelles, have similar chemical structures (Penumetcha et al. 2002). In contrast, Eder et al. (2003) found no difference in the uptake of labelled LDL in rats fed either unoxidised or oxidised fats, by J774 mouse macrophages.

Animal studies. Results of studies in rats show that dietary peroxides were the major source of peroxides found in serum lipoproteins, and that these were correlated with peroxides in plasma chylomicrons (Staprans et al. 1993b). Very low levels of peroxides were found in serum lipoproteins when rats were fed a fat-free diet. However, after the addition of $1 \mathrm{ml}$ oxidised maize oil $\left(100^{\circ} \mathrm{C}\right.$ for $1 \mathrm{~h}$; high PV) to the diet, there was a 5-fold increase in peroxide levels in the serum lipoprotein of healthy rats, and a 16-fold increase in diabetic rats compared with those on a control diet. A similar effect could increase oxidative stress in human consumers and could therefore have adverse cardiovascular effects (Esterbauer et al. 1993; Staprans et al. 1994).

Sulzle et al. (2004) showed that the intake of oxidised lipids altered lipid metabolism in rats. Rats were fed a diet containing $10 \%$ fat or a control diet. The fat was a mixture of sunflower-seed oil and lard that was either oxidised (38 d at $50{ }^{\circ} \mathrm{C}$ ) or unoxidised. Various genes were upregulated after consumption of the diet containing oxidised oil, but not by the control diet. The upregulated genes were related to cytochrome $\mathrm{P} 450, \beta$-oxidation, lipid metabolism and protein metabolism. For instance, there was a 14-fold upregulation of cytochrome P450A. Similarly, Chao and coworkers observed a 5-fold upregulation in P450A expression in rats fed a $20 \%$ oxidised soyabean-oil diet (Chao et al. 2004).

Such cytochrome P450A activation is believed to increase oxidative stress in rats, man and rabbits, and may therefore lead to an increase in the risk of CVD (Fleming, 2004; Thum \& Borlak, 2004; Zangar et al. 2004). Some have suggested that the induction of cytochrome P450A was caused by the activation of PPAR $\alpha$ expression in rats (Sulzle et al. 2004). However, if this is the case, it is less likely to be an issue in humans, as they have significantly less PPAR $\alpha$ than rats (Holden \& Tugwood, 1999).
Chylomicron metabolism is an important factor in postprandial lipid metabolism. A delay in chylomicron remnant clearance has been linked to premature coronary sclerosis and thrombosis (Patsch et al. 1992; Weintraub et al. 1996; Roche \& Gibney, 2000; Karpe et al. 2001). Chylomicron uptake of cholesterol by the liver was inhibited by $33 \%$ in rats fed a diet containing $1 \mathrm{ml}$ thermally oxidised maize oil $\left(1 \mathrm{~h}\right.$ at $\left.100^{\circ} \mathrm{C}\right)$. This was thought to be due to a $30 \%$ reduction in hydrolysis of chylomicrons containing oxidised lipids by endothelial lipoprotein lipase (Staprans et al. 1993a). There was also a $40 \%$ increase in chylomicron binding to the heart endothelium in rats fed thermally oxidised maize oil compared with unheated maize oil.

LDL-receptor-deficient mice fed a high-fat diet with or without oxidised linoleic acid have also been used in several studies (Khan-Merchant et al. 2002; Penumetcha et al. 2002). Mice fed a diet containing $21 \%$ enzymatically oxidised (using lipoxygenase) linoleic acid were found to have cholesterol levels that were $33 \%$ higher than those fed an equicaloric diet containing non-oxidised fat (Penumetcha et al. 2002). As with $\mathrm{CaCo}-2$ cells, this effect was thought to be due to the increased solubility of oxidised lipids, resulting in increased uptake of cholesterol in the presence of oxidised linoleic acid (Penumetcha et al. 2002). Levels of plasma LDL-cholesterol increased by $26 \%$ in mice fed a $21 \%$ fat diet containing 13-HODE compared with those fed the same diet without oxidised fat (Khan-Merchant et al. 2002). In another study, cholesterol levels in both LDL and HDL fractions were found to be approximately $35 \%$ lower in pigs fed a diet containing $15 \%$ thermally oxidised sunflower-seed oil $\left(48 \mathrm{~h}\right.$ at $\left.110^{\circ} \mathrm{C}\right)$ and lard $(94: 6 ; \mathrm{w} / \mathrm{w})$ (Eder \& Stangl, 2000).

Human studies. In one study (Naruszewicz et al. 1987), five human subjects were fed a meal containing $100 \mathrm{~g}$ untreated soyabean oil followed the next day by an identical meal containing the same quantity of oxidised soyabean oil (heat-treated for $7 \mathrm{~h}$ at $220^{\circ} \mathrm{C}$ ). On each occasion, blood samples were taken just before the test meal and then $4 \mathrm{~h}$ afterwards. On both days, plasma chylomicrons were isolated and incubated with mouse peritoneal macrophages for $48 \mathrm{~h}$. There was a 10 -fold increase in the concentration of cholesteryl esters in macrophages incubated with chylomicrons from participants who had consumed the thermally oxidised soyabean oil meal. In addition, the chylomicrons containing oxidised lipids were more quickly degraded by the macrophages. This suggested that there had been a substantial alteration in the composition of triacylglycerol-rich lipoproteins following consumption of oxidised soyabean oil, but not with fresh soyabean oil.

Summary of effects of oxidised lipids on lipid and chylomicron metabolism. Evidence indicates that dietary oxidised lipids are both absorbed and metabolised, and also alter the metabolism of cholesterol in all three models. In most studies, oxidised lipids were shown to increase the uptake of cholesterol and levels of total cholesterol. This is likely to be a result of an increase in the solubility of lipoproteins in micelles. These effects, along with the 
inhibition of cholesterol re-uptake by the liver, have the potential to increase the risk of atherosclerosis.

\section{Effects on oxidative stress}

Oxidative stress is considered to be an important factor in the development of CVD. Oxidative stress is indicated by increases in oxidised products, increased activity of enzymes involved in reducing oxidative stress or a reduction in tissue levels of antioxidants. The intake of oxidised lipids is known to affect several of these oxidative stress markers.

Cellular studies. 13-HPODE has been shown to increase the production of $\mathrm{H}_{2} \mathrm{O}_{2}$ (a free radical generator) in endothelial and smooth muscle cells (Santanam et al. 1999). As a result, the expression of catalase (an antioxidant enzyme) is increased in various cell types when incubated with 13-HPODE. Catalase expression increased 2.7-fold, 7fold and 1.5-fold in rabbit smooth muscle cells, mouse macrophages (RAW 264.1) and human umbilical vascular endothelial cells respectively (Meilhac et al. 2000). Such increases indicate that 13-HPODE is able to increase oxidative stress in cells. In addition, Wang et al. (2000) found that incubation of $\mathrm{CaCo}-2$ cells with HPODE led to a redox imbalance, as demonstrated by an 8 -fold increase in apoptotic cell deaths and a dose-dependent increase in DNA fragmentation.

Animal studies. Several studies in rats have found an increase in oxidation products in both serum and liver lipoproteins when the rats were fed diets containing oxidised oils. When rats were fed oxidised $\left(50^{\circ} \mathrm{C}\right.$ for $\left.16 \mathrm{~d}\right)$ sunflower-seed and linseed oils (80:20, w/w), there was a significant doubling in lipid HPODE and thiobarbituric acid-reactive substances (a secondary marker of lipid oxidation) found in the liver compared with the control diet containing non-oxidised oil (Brandsch \& Eder, 2004). In line with these findings, liver $\alpha$-tocopherol levels decreased by $50 \%$ in rats fed a $10 \%$ fat-based diet containing thermally oxidised oils $\left(50^{\circ} \mathrm{C}\right.$ for $16 \mathrm{~d}$; Brandsch et al. 2004).

A diet containing $10 \%$ thermally oxidised oils $\left(50^{\circ} \mathrm{C}\right.$ for $16 \mathrm{~d})$ significantly decreased levels of reduced glutathione (the main intracellular non-enzymatic antioxidant), glutathione peroxidase (an antioxidant enzyme) and catalase activity in rat erythrocytes (Keller et al. 2004). In another study, the lag phase of LDL oxidation was significantly reduced (10-25\% depending on the degree of oxidation) when rats were fed a mixture of sunflower-seed oil and lard $(31: 69, w / w)$ that had been oxidised to various degrees by varying heating times and temperatures (Eder et al. 2003). This increased susceptibility of LDL to oxidation has been associated with a higher risk of atherosclerosis (Berliner \& Heinecke, 1996; Steinberg, 1997; Chisolm \& Steinberg, 2000).

Garrido-Polonio et al. (2004) found that feeding rats a diet containing highly oxidised sunflower-seed oil as a result of repeated deep-fat frying, increased serum thiobarbituric acid-reactive substances by $80 \%$ compared with rats fed an identical diet containing non-oxidised fat. Again, these observed changes suggest that oxidised lipids increase the likelihood of atherosclerosis. Furthermore, a significant decrease in reduced erythrocyte glutathione and $\alpha$ tocopherol levels was observed in guinea-pigs fed $10 \%$ oxidised $\left(50^{\circ} \mathrm{C}\right.$ for $\left.16 \mathrm{~d}\right)$ oil (Keller et al. 2004).

Eder \& Stangl (2000) showed that levels of plasma tocopherol were reduced by $60 \%$ and LDL by $30 \%$ in pigs fed an oxidised fat $\left(48 \mathrm{~h}\right.$ at $\left.110^{\circ} \mathrm{C}\right)$ diet. These decreases were accompanied by a significant reduction in the tocopherol:lipids ratio. However, in contrast to other findings, there was no significant difference observed in the LDL lag phase, suggesting that lipoproteins were similarly susceptible to oxidation regardless of diet. This unexpected finding may have been due to the relatively high levels of $\mathrm{Cu}$ used to initiate the LDL oxidation $(50 \mu \mathrm{M})$, which would have led to an immediate oxidation of LDL (no lag phase) regardless of diet. Had a lower level of $\mathrm{Cu}$ (for example, $5 \mu \mathrm{M}$ ) been used, as is usually the case, then differences between diets may have been observed.

Human studies. The oxidised lipids consumed by six human subjects fed a meal containing thermally oxidised $\left(100^{\circ} \mathrm{C}\right.$ for $\left.3 \mathrm{~h}\right)$ maize oil $(1 \mathrm{~g} / \mathrm{kg}$ body weight $)$ were found to be the major source of oxidised products found in each participant's plasma (Staprans et al. 1994). There was a 4.7fold increase in the concentration of conjugated dienes (a marker of lipid HPODE) in the postprandial chylomicron fraction of those fed the oxidised oil. In other studies, consumption of the oxidised oil caused a significant increase in the level of oxidative products (as shown by thiobarbituric acid-reactive substances) in the chylomicron fraction of plasma (Naruszewicz et al. 1987; Staprans et al. 1994).

The oxidative lag time of plasma LDL-cholesterol obtained from volunteers fed oxidised (exposed to air for 6-8 weeks) maize oil ( $1 \mathrm{~g} / \mathrm{kg}$ body weight) was also reduced by approximately $25 \%$ compared with control (Staprans et al. 1994). This reduction in lag phase again indicates that LDL is more susceptible to oxidation, and is thus conducive to the development of atherosclerosis (Witztum \& Steinberg, 1991; Parks et al. 1998). An even larger reduction in the LDL lag phase $(50 \%)$ was observed when human subjects were fed a meal containing $400 \mathrm{mg}$ oxidised cholesterol ( $\alpha$-epoxy cholesterol) compared with a control meal (Staprans et al. 2003).

Oxidised lipids also affect the activity of paraoxonase. Low paraoxonase activity is seen in individuals at high risk of CHD (Mackness et al. 2003). In fact, the inhibitory effect of HDL-cholesterol on LDL-cholesterol oxidation has been partially attributed to paraoxonase in HDL-cholesterol (Mackness et al. 1993). In addition, mice with reduced paraoxonase activity have been found to be more susceptible to atherosclerosis (Durrington et al. 2001).

Sutherland et al. (1999) found that postprandial serum paraoxonase activity was $17 \%$ lower than baseline $4 \mathrm{~h}$ after the consumption of a meal containing $46 \mathrm{~g}$ thermally oxidised fat. This fat had been obtained from a fast-food restaurant just before its replacement with fresh fat and was equivalent to the fat content of an average fish-and-chip meal. As might be expected, this decrease in paraoxonase activity was accompanied by an increase in the peroxide concentration found in the LDL-cholesterol of participants fed the oxidised fat (Sutherland et al. 1999). 
Conversely, paraoxonase activity increased by $14 \%$ when an identical meal containing previously unused fat was consumed (Sutherland et al. 1999). In contrast, individuals with diabetes showed no reduction in paraoxonase activity after consuming $60 \mathrm{~g}$ thermally oxidised fat (Wallace $e t$ al. 2001), but this may have been due to the already high oxidative load in individuals with diabetes (Bucala et al. 1994; Basta et al. 2004).

Summary of effects of dietary oxidised lipids on oxidative stress. Various markers of oxidative stress and redox balance are affected by oxidised lipids. These include increases in markers of oxidisability (LDL oxidation lag phase; thiobarbituric acid-reactive substances and lipid HPODE), a reduction in plasma levels of dietary antioxidants ( $\alpha$-tocopherol) and modification of antioxidant enzyme activities (catalase and glutathione peroxidase).

\section{Effects on inflammation and vascular function}

Inflammation is widely recognised as a contributor to the atherosclerotic process (Ross, 1999; Glass \& Witztum, 2001). Fish oils are beneficial for anti-inflammatory, endothelial and other vascular functions (Khan et al. 2003; Schmidt et al. 2005a), but products of lipid oxidation may nullify these beneficial effects.

Cellular studies. Cell studies have indicated that oxidised linoleic acid inflames smooth muscle cells. 13-HPODE induces cell-surface expression of vascular and intracellular adhesion molecules in human umbilical vascular endothelial cells (Khan et al. 1995). Such expression of cell adhesion molecules is thought to be an early event in the development of inflammation and atherosclerotic plaques (Davies et al. 1993; Li et al. 1993). In addition, 13-HPODE increases the vascular cellular adhesion molecule expression both in porcine and human vascular smooth muscle cells, thus promoting an inflammatory response, whereas 13-HODE does not (Natarajan et al. 2001).

13-HPODE also activates kinase 3-fold in porcine aortic cells (Natarajan et al. 2001) and 4-fold in rat aortic cells (Rao et al. 1995). Such increased kinase expression is proinflammatory, and therefore 13-HPODE can be considered both pro-inflammatory and atherosclerotic (Natarajan \& Nadler, 2004). In addition, a significant increase in caspase3 activity was observed when intestinal epithelial $\mathrm{CaCo}-2$ cells were incubated with HPODE, providing further evidence of pro-inflammatory activation (Cohen, 1997; Fuentes-Prior \& Salvesen, 2004).

13-HPODE also activates monocyte chemoattractant protein-1, an inflammatory marker for increased risk of CVD, in human vascular smooth muscle cells (Dwarakanath et al. 2004). 9- and 13-HPODE both induce cytotoxicity in rat vascular smooth muscle cells via production of the superoxide anion following activation of NAD(P)H oxidase. However, Dwarakanath et al. (2004) found that the corresponding HODE do not have this effect.

Sethi (2002) suggested that oxidised EPA may underlie the anti-inflammatory effects of $n-3$ PUFA in fish oil. This conclusion was based on a single experiment in human endothelial cells and mice. Results showed that oxidised EPA was better than EPA at inhibiting the adhesion of leucocytes to endothelial cells. These results can be explained because oxidised EPA is a better activator of PPAR $\alpha$ than EPA in mice (Sethi, 2002). However, the finding is not likely to be relevant in humans, as rodents have much higher levels of PPAR $\alpha$ (Auboeuf et al. 1997; Holden \& Tugwood, 1999).

Animal studies. Animals fed oxidised lipids are at increased risk of developing atherosclerosis (Schwartz et al. 1991). Atherosclerotic lesions in the aorta of mice fed 13 -HODE $(8 \mathrm{mg} / \mathrm{d})$, were twice the size of those fed unoxidised linoleic acid (Penumetcha et al. 2002). Inclusion of 13-HODE in the diet increased the total:HDL-cholesterol ratio by $15-25 \%$ depending on levels of fat and cholesterol in the background diet. Similar effects on atherosclerotic lesions and oxidised cholesterol products were observed in both LDL receptor- and apo E-deficient mice when they were fed $5-10 \%$ oxidised cholesterol (1\% of diet, w/w) compared with a diet containing unoxidised cholesterol (Staprans et al. 2000).

Similarly, in rabbits fed a diet containing thermally oxidised maize oil $\left(2 \mathrm{~h}\right.$ at $\left.100^{\circ} \mathrm{C}\right)$ containing $120 \mathrm{mg}$ oxidised fatty acids/d, aortic lesions doubled in size, and a $2 \cdot 5$-fold increase in total cholesterol and a 4-fold increase in cholesteryl esters were observed in their pulmonary arteries (Staprans et al. 1996).

Human studies. Endothelium-dependent dilation in human subjects was adversely affected by the consumption of thermally oxidised fat obtained from a fast-food restaurant (Williams et al. 1999). Indeed, endotheliumdependent dilation decreased more than 7-fold after the consumption of a meal containing thermally oxidised fat (46 $\mathrm{g}$ oxidised fat obtained from the deep-fat fryer of a restaurant) compared with either equicaloric low-fat meal or a meal containing previously unused fat. This decrease in dilation would be detrimental to the function of the endothelium and is thought to be an important initial event in atherogenesis (Ross, 1993; Sader \& Celermajer, 2002).

Twenty-five volunteers were fed a meal containing walnut oil $(30 \mathrm{ml})$ that contained $26 \mathrm{mg}$ hydroxy fatty acids (Wilson et al. 2003). After 6h, HODE levels in the volunteers' plasma had doubled, indicating that oxidised lipids in the diet could be absorbed. Following stepwise regression analysis, the intake of plasma hydroxy fatty acids was also found to be a significant predictor of postprandial factor VIIa levels $\left(r^{2} 0.56 ; P=0.007\right)$. Plasma factor VIIa is the activated form of factor VII (Roche et al. 1998; Sanders et al. 2000; Miller et al. 2002) and higher levels of plasma factor VII are an indicator of increased risk of thrombosis, and therefore CHD, in middle-aged men (Meade et al. 1986; Golino, 2002; Lefevre et al. 2004).

Summary of the effects of dietary oxidised lipids on inflammation and vascular function. The results of cellular studies provide a strong basis for the proinflammatory effects of oxidised lipids, and animal and human studies indicate that vascular function is compromised by the consumption of oxidised lipids. However, vascular function is a complex area and the studies mentioned have various limitations. 


\section{Potential limitations}

Most cellular studies have focused on the 13-HPODE of linoleic acid but others have also looked at the 9-HPODE and HODE of linoleic acid. It is important to note that while other fatty acids such as, DHA and EPA are known to yield different HPODE as their initial breakdown products, these have not been studied.

The concentration of oxidation products will also vary significantly depending on the method and conditions of oxidation (Frankel, 2005). In the animal and human studies mentioned, the source of oxidised lipid used and the degree of oxidation varied substantially between trials, meaning that the concentration and identity of the oxidised lipid species also varied.

Only a few human trials have been done, the sample sizes have been small, and most have been in individuals with medical conditions. Until larger studies are done it is difficult to draw firm conclusions about the likely impact of oxidised lipids in human subjects. Despite this, animal and human studies have consistently shown that consumption of oxidised lipids has a significant effect on a range of biomarkers, including lipid metabolism, oxidative stress and vascular function that are known to adversely affect health.

\section{Conclusions and recommendations}

Oxidised lipids have numerous harmful effects on health, including the potential to increase the risk of atherosclerosis and thrombosis. These effects have been seen with relatively low levels of oxidised product, similar to those that could be obtained from the regular consumption of fish oil capsules. While products of oxidation in fish oils have not been considered previously, one would have to assume that they too are likely to affect health based on the evidence presented in this review. Indeed, oxidation products could account for the varying degrees of effectiveness and other inconsistencies associated with fish oil supplementation that have been reported in the literature.

To enable an accurate evaluation of the effects of oxidised fish oils, it is important that levels of oxidised product in fish oil are taken into account when designing studies involving fish oil supplementation. Reports of relevant studies should state (1) levels of HPODE and/or other oxidation products in the capsules at the start and completion of recruitment; (2) which antioxidants, if any, and at what concentrations, have been added to the oil to inhibit lipid oxidation; (3) the complete fatty acid composition of the oil used, because different fatty acids have different rates of oxidation.

\section{References}

Adams PB, Lawson S, Sanigorski A \& Sinclair AJ (1996) Arachidonic acid to eicosapentaenoic acid ratio in blood correlates positively with clinical symptoms of depression. Lipids 31, S157-S161.

Aidos I, van der Padt A, Boom RM \& Luten JB (2001) Upgrading of maatjes herring byproducts: production of crude fish oil. Journal of Agricultural and Food Chemistry 49, 3697-3704.

American Oil Chemists Society (1998) American Oil Chemists Society Official Methods and Recommended Practices, Pasaanisdine Value, Method CD 18-19. Champaign, IL: AOCS Press.
Association of Official Analytical Chemists (1990) Peroxide Value Method 965.33, 15th ed. Arlington, VA: Association of Official Analytical Chemists.

Auboeuf D, Rieusset J, Fajas L, Vallier P, Frering V, Riou JP, Staels P, Auwerx J, Laville M \& Vidal H (1997) Tissue distribution and quantification of the expression of mRNAs of peroxisome proliferator-activated receptors and liver X receptoralpha in humans - no alteration in adipose tissue of obese and NIDDM patients. Diabetes 46, 1319-1327.

Baik MY, Suhendro EL, Nawar WW, McClements DJ, Decker EA \& Chinachoti P (2004) Effects of antioxidants and humidity on the oxidative stability of microencapsulated fish oil. Journal of the American Oil Chemists Society 81, 355-360.

Barlow S (2000) Fishmeal and fish oil: sustainable feed ingredients for aquafeeds. Global Aquacultulture Advocate 4, 85-88.

Basta G, Schmidt AM \& De Caterina R (2004) Advanced glycation end products and vascular inflammation: implications for accelerated atherosclerosis in diabetes. Cardiovascular Research 63, 582-592.

Berliner JA \& Heinecke JW (1996) The role of oxidized lipoproteins in atherogenesis. Free Radical Biology and Medicine 20, 707-727.

Bimbo AP (1987) The emerging marine oil industry. Journal of the American Oil Chemists Society 64, 706-715.

Brandsch C \& Eder K (2004) Effects of peroxidation products in thermoxidised dietary oil in female rats during rearing, pregnancy and lactation on their reproductive performance and the antioxidative status of their offspring. British Journal of Nutrition 92, 267-275.

Brandsch C, Nass N \& Eder K (2004) A thermally oxidized dietary oil does not lower the activities of lipogenic enzymes in mammary glands of lactating rats but reduces the milk triglyceride concentration. Journal of Nutrition 134, 631-636.

Bucala R, Makita Z, Vega G, Grundy S, Koschinsky T, Cerami A \& Vlassara H (1994) Modification of low-density lipoprotein by advanced glycation end-products contributes to the dyslipidemia of diabetes and renal-insufficiency. Proceedings of the National Academy of Sciences U S A 91, 9441-9445.

Bucher HC, Hengstler P, Schindler C \& Meier G (2002) n-3 Polyunsaturated fatty acids in coronary heart disease: a metaanalysis of randomized controlled trials. American Journal of Medicine 112, 298-304.

Buckley R, Shewring B, Turner R, Yaqoob P \& Minihane AM (2004) Circulating triacylglycerol and apoE levels in response to EPA and docosahexaenoic acid supplementation in adult human subjects. British Journal of Nutrition 92, 477-483.

Burr ML, Gilbert JF, Holliday RM, Elwood PC, Fehily AM, Rogers S, Sweetnam PM \& Deadman NM (1989) Effects of changes in fat, fish, and fiber intakes on death and myocardial reinfarction - Diet and Reinfarction Trial (Dart). Lancet ii, $757-761$.

Calder PC (2004a) n-3 Fatty acids and cardiovascular disease: evidence explained and mechanisms explored. Clinical Science 107, $1-11$.

Calder PC (2004b) n-3 Fatty acids, inflammation, and immunity relevance to postsurgical and critically ill patients. Lipids 39, 1147-1161.

Chao PM, Hsu SC, Lin FJ, Li YJ \& Huang CJ (2004) The upregulation of hepatic acyl-CoA oxidase and cytochrome P-450 4A1 mRNA expression by dietary oxidized frying oil is comparable between male and female rats. Lipids 39, 233-238.

Chisolm GM \& Steinberg D (2000) The oxidative modification hypothesis of atherogenesis: an overview. Free Radical Biology and Medicine 28, 1815-1826.

Cleland LG, James MJ \& Proudman SM (2003) The role of fish oils in the treatment of rheumatoid arthritis. Drugs 63, 845-853. 
Cohen GM (1997) Caspases: the executioners of apoptosis. Biochemical Journal 326, 1-16.

Davies MJ, Gordon JL, Gearing AJH, Pigott R, Woolf N, Katz D \& Kyriakopoulos A (1993) The expression of the adhesion molecules Icam-1, Vcam-1, Pecam, and E-selectin in human atherosclerosis. Journal of Pathology 171, 223-229.

De Caterina R, Madonna R, Zucchi R \& La Rovere MT (2003) Antiarrhythmic effects of omega-3 fatty acids: from epidemiology to bedside. American Heart Journal 146, 420-430.

Durrington PN, Mackness B \& Mackness MI (2001) Paraoxonase and atherosclerosis. Arteriosclerosis Thrombosis and Vascular Biology 21, 473-480.

Dwarakanath RS, Sahar S, Reddy MA, Castanotto D, Rossi JJ \& Natarajan R (2004) Regulation of monocyte chemoattractant protein-1 by the oxidized lipid, 13-hydroperoxyoctadecadienoic acid, in vascular smooth muscle cells via nuclear factor-kappa B (NF-kappa B). Journal of Molecular and Cellular Cardiology 36, 585-595.

Eder K, Keller U, Hirche F \& Brandsch C (2003) Thermally oxidized dietary fats increase the susceptibility of rat LDL to lipid peroxidation but not their uptake by macrophages. Journal of Nutrition 133, 2830-2837.

Eder K \& Stangl GI (2000) Plasma thyroxine and cholesterol concentrations of miniature pigs are influenced by thermally oxidized dietary lipids. Journal of Nutrition 130, 116-121.

Esterbauer H, Wag G \& Puhl H (1993) Lipid peroxidation and its role in atherosclerosis. British Medical Bulletin 49, 566-576.

Fleming I (2004) Cytochrome P450 enzymes in the vasculature. Journal of Molecular and Cellular Cardiology 36, 728-729.

Frankel EN (1991) Recent advances in lipid oxidation. Journal of Science, Food and Agriculture 54, 489-511.

Frankel EN (2005) Lipid Oxidation, 2nd ed. Bridgwater, UK: The Oily Press.

Fritsche KL \& Johnston PV (1987) Rapid autoxidation of fish oil in diets without added antioxidants. Journal of Nutrition 118, 425-426.

Fuentes-Prior P \& Salvesen GS (2004) The protein structures that shape caspase activity, specificity, activation and inhibition. Biochemical Journal 384, 201-232.

Garrido-Polonio C, Garcia-Linares MC, Garcia-Arias MT, LopezVarela S, Garcia-Fernandez MC, Terpstra AH \& Sanchez-Muniz FJ (2004) Thermally oxidised sunflower-seed oil increases liver and serum peroxidation and modifies lipoprotein composition in rats. British Journal of Nutrition 92, 257-265.

Glass CK \& Witztum JL (2001) Atherosclerosis: the road ahead. Cell 104, 503-516.

Golino P (2002) The inhibitors of the tissue factor: factor VII pathway. Thrombosis Research 106, V257-V265.

Gunstone F (1999) Fatty Acid and Lipid Chemistry. Glasgow: Blackie Academic and Professional.

Hamilton RJ, Kalu C, McNeill GP, Padley FB \& Pierce JH (1998) Effects of tocopherols, ascorbyl palmitate, and lecithin on autoxidation of fish oil. Journal of the American Oil Chemists Society 75, 813-822.

Harris WS (1997) n-3 Fatty acids and serum lipoproteins: human studies. American Journal of Clinical Nutrition 65, S1645-S1654

Harrison N \& Abhyankar B (2005) The mechanism of action of omega-3 fatty acids in secondary prevention of postmyocardial infarction. Current Medical Research and Opinion 21, 95-100.

Helland IB, Smith L, Saarem K, Saugstad OD \& Drevon CA (2003) Maternal supplementation with very-long-chain n-3 fatty acids during pregnancy and lactation augments children's IQ at 4 years of age. Pediatrics 111, 39-44.

Heude B, Ducimetiere P \& Berr C (2003) Cognitive decline and fatty acid composition of erythrocyte membranes - the EVA Study. American Journal of Clinical Nutrition 77, 803-808.
Hibbeln JR (1998) Fish consumption and major depression. Lancet 351, 1213.

Holden PR \& Tugwood JD (1999) Peroxisome proliferatoractivated receptor alpha: role in rodent liver cancer and species differences. Journal of Molecular Endocrinology 22, 1-8.

Hu FB \& Willett WC (2002) Optimal diets for prevention of coronary heart disease. Journal of the American Medical Association 288, 2569-2578.

Jorgensen MH, Lauritzen L \& Fleischer-Michaelsen K (1999) The role of long-chain polyunsaturated fatty acids in neonatal nutrition. Acta Paediatrica 88, 916-917.

Karpe F, Boquist S, Tang R, Bond GM, de Faire U \& Hamsten A (2001) Remnant lipoproteins are related to intima-media thickness of the carotid artery independently of LDL cholesterol and plasma triglycerides. Journal of Lipid Research 42, 17-21.

Kaul U, Sanghvi S, Bahl VK, Dev V \& Wasir HS (1992) Fish oil supplements for prevention of restenosis after coronary angioplasty. International Journal of Cardiology 35, 87-93.

Keller U, Brandsch C \& Eder K (2004) The effect of dietary oxidized fats on the antioxidant status of erythrocytes and their susceptibility to haemolysis in rats and guinea pigs. Journal of Animal Physiology and Animal Nutrition 88, 59-72.

Kew S, Mesa MD, Tricon S, Buckley R, Minihane AM \& Yaqoob P (2004) Effects of oils rich in eicosapentaenoic and docosahexaenoic acids on immune cell composition and function in healthy humans. American Journal of Clinical Nutrition 79, 674-681.

Khan BV, Parthasarathy SS, Alexander RW \& Medford RM (1995) Modified low-density lipoprotein and its constituents augment cytokine activated vascular cell adhesion molecule-1 gene expression in human vascular endothelial cells. Journal of Clinical Investigation 95, 1262-1270.

Khan F, Elherik K, Bolton-Smith C, Barr R, Hill A, Murrie I \& Belch JJF (2003) The effects of dietary fatty acid supplementation on endothelial function and vascular tone in healthy subjects. Cardiovascular Research 59, 955-962.

Khan-Merchant N, Penumetcha M, Meilhac O \& Parthasarathy S (2002) Oxidized fatty acids promote atherosclerosis only in the presence of dietary cholesterol in low-density lipoprotein receptor knockout mice. Journal of Nutrition 132, 3256-3262.

Khayat A \& Schwall D (1983) Lipid oxidation in seafood. Food Technology 37, 130-140.

Kris-Etherton PM, Harris WS \& Appel LJ; Nutrition Committee (2003) Fish consumption, fish oil, omega-3 fatty acids and cardiovascular disease. Arteriosclerosis, Thrombosis and Vascular Biology 23, E20-E31.

Lee KW \& Lip GYH (2003) The role of omega-3 fatty acids in the secondary prevention of cardiovascular disease. QJM: an International Journal of Medicine 96, 465-480.

Lefevre M, Kris-Etherton PM, Zhao G \& Tracy RP (2004) Dietary fatty acids, hemostasis, and cardiovascular disease risk. Journal of the American Dietetic Association 104, 410-419.

Leigh-Firbank EC, Minihane AM, Leake DS, Wright JW, Murphy MC, Griffin BA \& Williams CM (2002) Eicosapentaenoic acid and docosahexaenoic acid from fish oils: differential associations with lipid responses. British Journal of Nutrition 87, $435-445$.

Li HM, Cybulsky MI, Gimbrone MA \& Libby P (1993) Inducible expression of vascular cell adhesion molecule-1 by vascular smooth muscle cells in vitro and within rabbit atheroma. American Journal of Pathology 143, 1551-1559.

Mackness B, Durrington P, McElduff P, Yarnell J, Azam N, Watt M \& Mackness M (2003) Low paraoxonase activity predicts coronary events in the Caerphilly prospective study. Circulation 107, 2775-2779.

Mackness MI, Arrol S, Abbott C \& Durrington PN (1993) Protection of low-density lipoprotein against oxidative 
modification by high-density lipoprotein associated paraoxonase. Atherosclerosis 104, 129-135.

Marckmann P \& Gronbaek M (1999) Fish consumption and coronary heart disease mortality. A systematic review of prospective cohort studies. European Journal of Clinical Nutrition 53, 585-590.

Meade TW, Brozovic M, Chakrabarti RR, Haines AP, Imeson JD, Mellows S, Miller GJ, North WRS, Stirling Y \& Thompson SG (1986) Hemostatic function and ischemic heart disease principal results of the Northwick Park heart study. Lancet ii, 533-537.

Meilhac O, Zhou M, Santanam N \& Parthasarathy S (2000) Lipid peroxides induce expression of catalase in cultured vascular cells. Journal of Lipid Research 41, 1205-1213.

Miller GJ, Cooke CJ, Nanjee MN, Howarth DJ, Cooper JA, Stepanova IP, Morrissey JH \& Miller NE (2002) Factor VII activation, apolipoprotein A-I and reverse cholesterol transport: possible relevance for postprandial lipaemia. Thrombosis and Haemostasis 87, 477-482.

Min DB \& Boff JM (2002) Chemistry and reaction of singlet oxygen in foods. Comparative Reviews in Food Science and Food Safety 1, 58-72.

Minihane AM, Khan S, Leigh-Firbank EC, Talmud P, Wright JW, Murphy MC, Griffin BA \& Williams CM (2000) ApoE polymorphism and fish oil supplementation in subjects with an atherogenic lipoprotein phenotype. Arteriosclerosis Thrombosis and Vascular Biology 20, 1990-1997.

Muller C, Friedrichs R, Wingler K \& Brigelius-Flohe R (2002) Perturbation of lipid metabolism by linoleic acid hydroperoxide in CaCo-2 cells. Biological Chemistry 383, 637-648.

Naruszewicz M, Wozny E, Mirkiewicz E, Nowicka G \& Szostak WB (1987) The effect of thermally oxidized soya bean oil on metabolism of chylomicrons - increased uptake and degradation of oxidized chylomicrons in cultured mouse macrophages. Atherosclerosis 66, 45-53.

Natarajan R \& Nadler JL (2004) Lipid inflammatory mediators in diabetic vascular disease. Arteriosclerosis, Thrombosis and Vascular Biology 24, 1542-1548.

Natarajan R, Reddy MA, Malik KU, Fatima S \& Khan BV (2001) Signaling mechanisms of nuclear factor-kappa B-mediated activation of inflammatory genes by 13-hydroperoxyoctadecadienoic acid in cultured vascular smooth muscle cells. Arteriosclerosis Thrombosis and Vascular Biology 21, $1408-1413$.

Okuda N, Ueshima H, Okayama A, Saitoh S, Nakagawa H, Rodriguez BL, Sakata K, Choudhury SR, Curb JD \& Stamler J (2005) Relation of long chain n-3 polyunsaturated fatty acid intake to serum high density lipoprotein cholesterol among Japanese men in Japan and Japanese-American men in Hawaii: the INTERLIPID study. Atherosclerosis 178, 371-379.

Parks EJ, German JB, Davis PA, Frankel EN, Kappagoda CT, Rutledge JC, Hyson DA \& Schneeman BO (1998) Reduced oxidative susceptibility of LDL from patients participating in an intensive atherosclerosis treatment program. American Journal of Clinical Nutrition 68, 778-785.

Passi S, Ricci R, Cataudella S, Ferrante I, De Simone F \& Rastrelli L (2004) Fatty acid pattern, oxidation product development, and antioxidant loss in muscle tissue of rainbow trout and Dicentrarchus labrax during growth. Journal of Agricultural and Food Chemistry 52, 2587-2592.

Patsch JR, Miesenbock G, Hopferwieser T, Muhlberger V, Knapp E, Dunn JK, Gotto AM \& Patsch W (1992) Relation of triglyceride metabolism and coronary artery disease - studies in the postprandial state. Arteriosclerosis and Thrombosis 12, 1336-1345.

Penumetcha M, Khan-Merchant N \& Parthasarathy S (2002) Enhanced solubilization and intestinal absorption of cholesterol by oxidized linoleic acid. Journal of Lipid Research 43 , 895-903.

Pokorny J, Yanishlieva N \& Gordon M (2001) Antioxidants in Food, 1st ed. Cambridge, UK: Woodhead Publishing Limited.

Rao GN, Alexander RW \& Runge MS (1995) Linoleic acid and its metabolites, hydroperoxyoctadecadienoic acids, stimulate CFos, C-Jun, and C-Myc messenger RNA expression, mitogen activated protein kinase activation, and growth in rat aortic smooth muscle cells. Journal of Clinical Investigation 96, $842-847$.

Richards MP \& Li R (2004) Effects of released iron, lipid peroxides, and ascorbate in trout hemoglobin-mediated lipid oxidation of washed cod muscle. Journal of Agricultural and Food Chemistry 52, 4323-4329.

Rivellese AA, Maffettone A, Vessby B, Uusitupa M, Hermansen K, Berglund L, Louheranta A, Meyer BJ \& Riccardi G (2003) Effects of dietary saturated, monounsaturated and n-3 fatty acids on fasting lipoproteins, LDL size and post-prandial lipid metabolism in healthy subjects. Atherosclerosis 167, 149-158.

Roche HM \& Gibney MJ (2000) The impact of postprandial lipemia in accelerating atherothrombosis. Journal of Cardiovascular Risk 7, 317-324.

Roche HM, Zampelas A, Knapper JME, Webb D, Brooks C, Jackson KG, Wright JW, Gould BJ, Kafatos A, Gibney MJ \& Williams CM (1998) Effect of long-term olive oil dietary intervention on postprandial triacylglycerol and factor VII metabolism. American Journal of Clinical Nutrition 68, $552-560$.

Ross R (1993) The pathogenesis of atherosclerosis - a perspective for the 1990s. Nature 362, 801-809.

Ross R (1999) Mechanisms of disease - atherosclerosis - an inflammatory disease. New England Journal of Medicine 340, $115-126$

Sader MA \& Celermajer DS (2002) Endothelial function, vascular reactivity and gender differences in the cardiovascular system. Cardiovascular Research 53, 597-604.

Sanders TAB, de Grassi T, Miller GJ \& Morrissey JH (2000) Influence of fatty acid chain length and cis/trans isomerization on postprandial lipemia and factor VII in healthy subjects (postprandial lipids and factor VII). Atherosclerosis 149, 413-420.

Santanam N, Auge N, Zhou M, Keshava C \& Parthasarathy S (1999) Overexpression of human catalase gene decreases oxidized lipid-induced cytotoxicity in vascular smooth muscle cells. Arteriosclerosis Thrombosis and Vascular Biology 19, $1912-1917$.

Schmidt EB, Arnesen H, de Caterina R, Rasmussen LH \& Kristensen SD (2005a) Marine n-3 polyunsaturated fatty acids and coronary heart disease - part I. Background, epidemiology, animal data, effects on risk factors and safety. Thrombosis Research 115, 163-170.

Schmidt EB, Arnesen H, Christensen JH, Rasmussen LH, Kristensen SD \& De Caterina R (2005b) Marine n-3 polyunsaturated fatty acids and coronary heart disease - part II: Clinical trials and recommendations. Thrombosis Research 115, 257-262.

Schwartz CJ, Valente AJ, Sprague EA, Kelley JL \& Nerem RM (1991) The pathogenesis of atherosclerosis - an overview. Clinical Cardiology 14, 1-16.

Sethi S (2002) Inhibition of leukocyte-endothelial interactions by oxidized omega-3 fatty acids: a novel mechanism for the antiinflammatory effects of omega- 3 fatty acids in fish oil. Redox Report 7, 369-378.

Silvers KM \& Scott KM (2002) Fish consumption and selfreported physical and mental health status. Public Health Nutrition 5, 427-431. 
Staprans I, Pan XM, Miller M \& Rapp JH (1993a) Effect of dietary lipid peroxides on metabolism of serum chylomicrons in rats. American Journal of Physiology 264, G561-G568.

Staprans I, Pan XM, Rapp JH \& Feingold KR (2003) Oxidised cholesterol in the diet is a source of oxidised lipoproteins in human serum. Journal of Lipid Research 44, 705-715.

Staprans I, Pan XM, Rapp JH, Grunfeld C \& Feingold KR (2000) Oxidized cholesterol in the diet accelerates the development of atherosclerosis in LDL receptor- and apolipoprotein E-deficient mice. Arteriosclerosis Thrombosis and Vascular Biology 20, $708-714$.

Staprans I, Rapp JH, Pan XM \& Feingold KR (1993b) The effect of oxidized lipids in the diet on serum lipoprotein peroxides in control and diabetic rats. Journal of Clinical Investigation 92, 638-643.

Staprans I, Rapp JH, Pan XM, Hardman DA \& Feingold KR (1996) Oxidized lipids in the diet accelerate the development of fatty streaks in cholesterol-fed rabbits. Arteriosclerosis Thrombosis and Vascular Biology 16, 533-538.

Staprans I, Rapp JH, Pan XM, Kim KY \& Feingold KR (1994) Oxidized lipids in the diet are a source of oxidized lipid in chylomicrons of human serum. Arteriosclerosis and Thrombosis 14, 1900-1905.

Steinberg D (1997) A critical look at the evidence for the oxidation of LDL in atherogenesis. Atherosclerosis 131, S5-S7.

Sulzle A, Hirche F \& Eder K (2004) Thermally oxidized dietary fat upregulates the expression of target genes of PPARa in rat liver. Journal of Nutrition 134, 1375-1383.

Sutherland WHF, Walker RJ, de Jong SA, van Rij AM, Phillips V \& Walker HL (1999) Reduced postprandial serum paraoxonase activity after a meal rich in used cooking fat. Arteriosclerosis Thrombosis and Vascular Biology 19, 1340-1347.

Theobald HE, Chowienczyk PJ, Whittall R, Humphries SE \& Sanders TAB (2004) LDL cholesterol-raising effect of low-dose docosahexaenoic acid in middle-aged men and women. American Journal of Clinical Nutrition 79, 558-563.

Thum T \& Borlak J (2004) Mechanistic role of cytochrome P450 monooxygenases in oxidized low-density lipoprotein-induced vascular injury - therapy through LOX-1 receptor antagonism? Circulation Research 94, E1-E13.

Undeland I, Ekstrand B \& Lingnert H (1998) Lipid oxidation in herring (Clupea harengus) light muscle, dark muscle, and skin, stored separately or as intact fillets. Journal of the American Oil Chemists Society 75, 581-590.

Valagussa F, Franzosi MG, Geraci E, Mininni N, Nicolosi GL, Santini M, Tavazzi L, Vecchio C, Marchioli R, Bomba E, et al. (1999) Dietary supplementation with n-3 polyunsaturated fatty acids and vitamin $\mathrm{E}$ after myocardial infarction: results of the GISSI-Prevenzione trial. Lancet 354, 447-455.

Venugopal V \& Shahidi F (1998) Traditional methods to process underutilized fish species for human consumption. Food Reviews International 14, 35-97.

Wallace AJ, Sutherland WHF, Mann JI \& Williams SM (2001) The effect of meals rich in thermally stressed olive and safflower oils on postprandial serum paraoxonase activity in patients with diabetes. European Journal of Clinical Nutrition 55, 951-958.

Wang TG, Gotoh Y, Jennings MH, Rhoads CA \& Aw TY (2000) Lipid hydroperoxide-induced apoptosis in human colonic $\mathrm{CaCo}-$ 2 cells is associated with an early loss of cellular redox balance. FASEB Journal 14, 1567-1576.

Weintraub MS, Grosskopf I, Rassin T, Miller H, Charach G, Rotmensch HH, Liron M, Rubinstein A \& Iaina A (1996) Clearance of chylomicron remnants in normolipidaemic patients with coronary artery disease: case control study over three years. British Medical Journal 312, 935-939.

Wilkinson P, Leach C, Ah-Sing EE, Hussain N, Miller GJ, Millward DJ \& Griffin BA (2005) Influence of alpha-linolenic acid and fish-oil on markers of cardiovascular risk in subjects with an atherogenic lipoprotein phenotype. Atherosclerosis 181, $115-124$.

Williams MJA, Sutherland WHF, McCormick MP, de Jong SA, Walker RJ \& Wilkins GT (1999) Impaired endothelial function following a meal rich in used cooking fat. Journal of the American College of Cardiology 33, 1050-1055.

Wilson R, Lyall K, Millar EM, Smyth L, Pearson C \& Riemersma RA (2003) Do oxidized fatty acids activate coagulation factor VII during post-prandial lipemia in women? Thrombosis and Haemostasis 89, 654-659.

Witztum JL \& Steinberg D (1991) Role of oxidized low-density lipoprotein in atherogenesis. Journal of Clinical Investigation 88, $1785-1792$.

Zangar RC, Davydov DR \& Verma S (2004) Mechanisms that regulate production of reactive oxygen species by cytochrome P450. Toxicology and Applied Pharmacology 199, 316-331. 